\title{
The Influence of Normative Beliefs on Tax-Payers Attitude and Voluntary Tax Compliance Intention
}

\author{
Ang Leng Soon, Chek Derashid*, Zainol Bidin \\ Tunku Puteri Intan Safinaz School of Accountancy, Universiti Utara Malaysia
}

\begin{abstract}
As technology advances, individuals will utilise the gadgets in their daily processes. However, individuals may still require views from their peers and other people surrounding in making decisions. The views formed would affect the individual's attitude towards their actions. This study was administered to understand the influence of normative belief on taxpayers' attitude towards voluntary tax compliance intention using the Theory of Reasoned Action (TRA). A total of 311 responses were obtained from the survey conducted remotely online, which was analysed using Smart PLS 3.0 software. The attitude (ATT) construct was decomposed into several dimensions of general tax filing knowledge, compatibility, perceived ease of use, perceived usefulness, and subjective norm. Interestingly, the study found that normative belief, which was measured using the dimension of the subjective norm, has a significant influence on attitude. Similarly, it was found that general tax filing knowledge does significantly influence attitude. However, the dimensions of compatibility, perceived ease of use, and perceived usefulness were found to be insignificant. In conclusion, the study recognises that technologies play an essential role in individuals' attitude on tax compliance. Nevertheless, the views of peers and tax knowledge do have an impact on taxpayers regardless of the compatibility and usefulness of the systems when it comes to the voluntary tax compliance intention.
\end{abstract}

Keywords: Voluntary Tax Compliance; Theory of Reasoned Action (TRA)

JEL Classification: M410

Paper Type: Research

*Corresponding author: E-mail: chek@uum.edu.my 


\section{INTRODUCTION}

Due to technological advancements, Inland Revenue Board of Malaysia (IRBM), as the tax administrators have tried its best to equip and to update themselves due to the increase in total delinquent taxpayers (Kasipillai \& Mohd Hanefah, 2000). Hence, the automated mode of facilities like e-filing, e-filling, and e-payment introduced by IRBM was aimed to increase tax payment compliance (IRBM, 2005, p. 18). The achievement of the Prime Minister's Innovation Award (AIPM) 2009 in 2010 (IRBM, 2011) proved IRBM's innovative effort towards raising the tax compliance rate. Despite the facilitation of advanced online tax systems that provides the ease to comply, the desired aim to maximise voluntary tax compliance by most tax administrators, particularly IRBM, was far from satisfactory level.

Although efforts by the Malaysian government to ensure compliance facilitation via the efiling system, the increased number of e-filers does not represent the overall increase in compliance rate regarding the income tax form submissions. Indisputably, the e-filing system for income tax form submission is preferable among individual taxpayers. This resulted in 96.88 percent among individual taxpayers who had filed their income tax forms had done it through the e-filing system in the year 2017. Furthermore, IRBM has been consistently achieving above 90 percent in the total number of e-filers that are similar to other countries like the USA (Apostolou, Dorminey, \& Schaupp, 2016), Taiwan (Chen, 2010) and United Kingdom (Lymer, Hansford, \& Pilkington, 2012). Nevertheless, in terms of overall voluntary tax compliance towards income tax form, submission among active individual taxpayers in Malaysia is still far from a satisfactory level.

Based on the statistics obtained from the Tax Operation Department of IRBM for the year 2017, the tax compliance rate was only 49.54 percent among total active individual taxpayers. Despite the rigorous action by IRBM to promote the e-filing system as an effective and efficient tax compliance tool, yet the majority of active individual taxpayers have not complied with the income tax laws towards submission of income tax form voluntarily. The reluctance of individual taxpayers to comply voluntarily with tax laws provides the indicator of voluntary tax compliance behaviour issues.

Noticeably, the significance of taxpayer's acceptance of the e-filing systems among individual taxpayers had minimalised the number of manual tax filers. However, the significance of the e-filing system is inadequately commensurable towards the increase of total active individual taxpayers in Malaysia. Furthermore, most of the individual taxpayers, especially those with employment income earners, are prone to submit self-completed income tax forms without any assistance from tax agents (Palil \& Mustapha, 2011; Trivedi, Shehata, \& Lynn, 2003). Hence, this resulted in having individual taxpayers to seek further assistance or clarifications from individuals or other sources of the referent in obtaining knowledge for self-voluntary tax compliance. In addition, it would be interesting to understand the influence of normative belief on taxpayer's attitude towards complying tax laws voluntarily. Furthermore, not many kinds of research focused on the impact of normative belief on attitudes, especially on tax studies. The above arguments provide the need for this study to focus on tax compliant intention through modified Theory of Reasoned Action (TRA). 


\section{LITERATURE REVIEW}

\subsection{Theory of Reasoned Action (TRA)}

As the improvised version of Expectancy Value Theory (EVT) (see Figure 1), the Theory of Reasoned Action (TRA) developed by Ajzen and Fishbein (1980) in the psychology field to predict human behavioural intention and action. The TRA that covers attitude and behaviour predictions suggests that that person's intention mainly drives an individual's behaviour. Besides, the individual's intention driven behaviour depends on the attitude and subjective norm in performing the behaviour (Ajzen \& Fishbein, 1980). Fishbein and Ajzen (1975, p. 201) define behavioural intention as "An individual's subjective probability that he or she will perform a specified behaviour." Accordingly, intentions that were included in the TRA model would provide better behavioural prediction with assumptions that the individuals made their rational decisions (Fishbein \& Ajzen, 1975).

Attitude as defined by Fishbein and Ajzen (1975, p. 216) as "An individual's positive or negative feelings (evaluative affect) about performing the target behaviour." The individual's salient belief of the outcome of their actions is referred to as attitude where salient belief is regarded as the immediate outcome of that individual's attitude (Ajzen \& Fishbein, 1980). The accumulation of experiences over time forms an individual's belief that determines the individual's attitude. However, the attitude only can be influenced by only a handful of these beliefs. As defined by Fishbein and Ajzen (1975, p. 302), subjective norm refers to "The person's perception that most people who are important to him think he should or should not perform the behaviour in question." The influence of individuals or groups on the person towards performing the perceived expectations is referred to as subjective norm (Fishbein \& Ajzen, 1975). The important people's influence on that particular person, which may approve or disapprove the said person's behavioural performance (normative beliefs), is assessed through the motivation to obey that person with regards to the referents (Ajzen \& Fishbein, 1980). Nevertheless, both subjective norms and attitudes have different outcome on behavioural intention and hence, have different weightage on a behavioural prediction that is not weighted equally (Fishbein \& Ajzen, 1975).

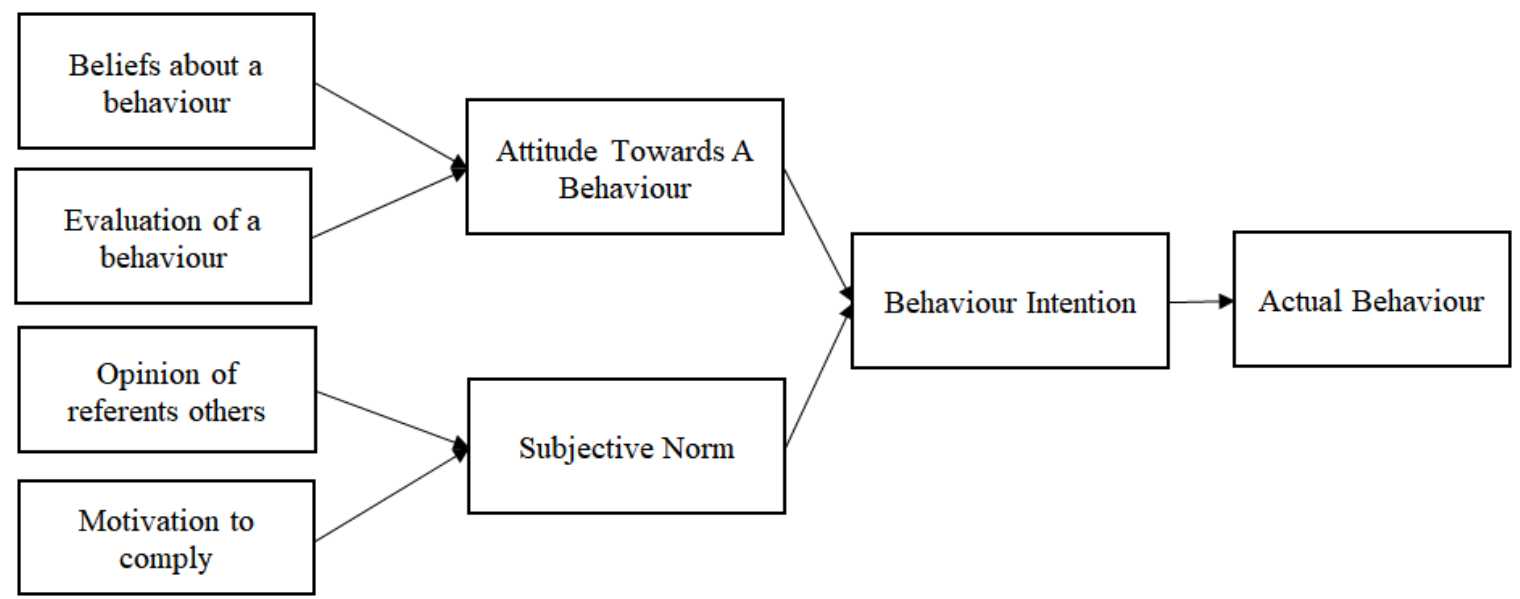

Figure 1. Theory of Reasoned Action (TRA) Source: Fishbein and Ajzen (1975) 
A meta-analysis by Sheppard, Hartwick, and Warshaw (1988) showed that TRA provides a powerful predictive utility with exceptional performance in predicting goals and activities. In addition, the researchers indicated that the initial TRA model, without choice element, was developed towards intention examination to perform a single behaviour. Where this study tax compliance intention that categorised as behaviour under volition control, the application of the TRA model is suggested for this study (Madden, Ellen, and Ajzen, 1992). For this study, the attitudinal factors are decomposed to the following factors - PEU, PU, COMP, GTFK, and SN.

\section{Attitude}

Attitudes can be referred to as the individual's salient beliefs about outcomes resulted from their actions. The salient belief refers to the immediate outcome, which determines the attitude of an individual (Ajzen \& Fishbein, 1980). The accumulated experience overtime forms the belief of individuals, which determines that individual's attitude, but which these few beliefs can only influence attitudes. Attitudes are learned through learning (from family, observation), following to others as well as solving a problem. Amongst the models that are used to measure attitude include the multi-attribute model. The basic multi-attribute model consists of three elements-attributes, beliefs, and weights. Attributes are the characteristics of the attitude object. Taxpayers generally have favourable attitudes towards products or services that have an adequate level of attributes. On the other hand, taxpayers may generally have unfavourable attitudes towards products or services without an adequate level of attributes.

Normative beliefs refer to the individual's beliefs on the extent where other referents, either individuals or groups which are vital to them, are in the view that they may or may not perform a particular behaviour. Individuals or groups referred may consist of family, friends, spouse, colleagues, or others, depending on the focus of the study's population (Ajzen, 1985). These normative beliefs, along with a person's motivation to comply based on various referents, are assumed will determine the subjective norm of that person. As represented in its equation, the subjective norm construct which is directly proportionate to the summation of the resulting products among the salient referents (Ajzen, 1991). As mentioned by Eckhardt, Laumer, and Weitzel (2009), studies showed mixed results in measuring peer influence, especially technology adoption studies.

Furthermore, the authors were in the opinion that referents might vary in sizes. Thus, it is an indicator that opinions or views from taxpayer's peers were remarkable in their decision-making processes. Hence, the subjective norm in this study refers to the influence of normative belief on taxpayers' attitude towards tax compliance.

Beliefs are a measurement of a particular attribute. Weights are the indications of importance or priority of a particular attribute. Taxpayers show their attitude toward behaving or acting concerning an object rather than the attitude toward the object itself. It is people related. In terms of weights, people generally crave acceptance by others. Attitude, on the other hand, plays a significant role in influencing intention. As such, the following hypotheses are derived:

H1: GTFK has a significant relationship with attitude.

$\mathrm{H} 2$ : COMP has a significant relationship with attitude.

H3: PEOU has a significant relationship with attitude.

H4: PU has a significant relationship with attitude.

H5: SN has a significant relationship with attitude 
According to Fishbein and Ajzen (1975), attitude towards a behaviour is positively related to the intention to engage in a behaviour. According to Schiffman and Kanuk (2010), a consumers' attitude toward an object, in this case, voluntary tax compliance is the level of importance placed by the taxpayers towards the e-filing platform as well as the taxpayers' perception of the level to which this platform possesses for each attribute. As such, the following hypothesis is derived:

H6: Attitude has a significant relationship with intention.

\section{METHODOLOGY}

A total of 311 responses were obtained from respondents received for analyses. The data collection was conducted on Employment sourced income individuals only with those nonMTD deductible employment income that were removed from the analyses. Respondents with both employment and business sourced income, in addition to those respondents with business incomed earners, were also being disregarded. As a process, a total of 8 responses were removed from the pool due to the above-said criteria. Hence, further analyses were conducted on all those valid responses using SPSS and Smart PLS 3.2.8 software. Previous literature, including the Inland Revenue Board of Malaysia (IRBM) website, was used to obtain scales that were adopted or adapted in this study. The scale items used in this study are as follow:

Table 1. Scales adapted/ adopted

\begin{tabular}{lclc}
\hline Constructs & Total items & Sources & Cronbach $\boldsymbol{\alpha}$ \\
\hline Intention (INT) & 3 & Taylor \& Todd (1995) & 0.91 \\
Attitude (ATT) & 4 & Taylor \& Todd (1995) & 0.85 \\
General Tax Filing Knowledge (GTFK) & 8 & IRBM website 2020 & NA \\
Perceived Usefulness (PU) & 8 & Taylor \& Todd (1995) & 0.68 \\
Perceived ease of use (PEOU) & 6 & Davis (1989) & 0.94 \\
Compatibility (COMP) & 6 & Taylor \& Todd (1995) & 0.82 \\
Subjective Norm (SN) & 4 & Taylor \& Todd (1995) & 0.88 \\
\hline
\end{tabular}

Before the full-scale data collection, a pilot study was conducted to ascertain the relevance of questions towards addressing the objective of this research. The Exploratory Factor Analysis (EFA) procedure was conducted using SPSS for the pilot study. Once the validity and reliability criteria of the pilot study were satisfied, full data collection was obtained for Confirmatory Factor Analysis (CFA). All the data from the survey collected were entered into SPSS and further analysed using Smart PLS 3.2.8. Hence, the subsequent sections discuss the findings of the analyses.

\section{RESULTS AND FINDINGS}

Most of the respondents were between the age of 25 to 64 years old group with no respondents from the age below 25 or above 65 years old. It is assumed that those below 25 years old are still studying while those above 65 have retired in which they may not be earning fixed taxable employment income or having a non-taxable income, or in the case of this study, they may be earning business income. The majority of respondents were married $(73 \%)$ and have obtained at least a bachelor's degree $(60.4 \%)$ that works in private sectors (46.9\%), which received a salary from employment income only (71\%). A total of $52.8 \%$ of respondents used personal computers to file their income tax form as 
compared to laptops (35\%), PDA/Smartphone/Handphone (8.9\%), and manual form (3.3\%). This indicates the preference of income tax filing mode by the majority of the respondents. Hence, the demographic details of the respondents were summarised below in Table 1.

Table 2. Demographic profile

\begin{tabular}{|c|c|c|c|}
\hline Details & Category & Frequency & Percentage \\
\hline \multirow[t]{7}{*}{ Age } & $15-24$ & 0 & 0.0 \\
\hline & $25-34$ & 55 & 18.2 \\
\hline & $35-44$ & 91 & 30.0 \\
\hline & $45-54$ & 87 & 28.7 \\
\hline & $55-64$ & 70 & 23.1 \\
\hline & $>65$ & 0 & 0.0 \\
\hline & Total & 303 & 100 \\
\hline \multirow[t]{4}{*}{ Marital Status } & Single & 64 & 21.1 \\
\hline & Married & 221 & 73.0 \\
\hline & Divorced & 18 & 5.9 \\
\hline & Total & 303 & 100 \\
\hline \multirow{6}{*}{$\begin{array}{l}\text { Highest level of } \\
\text { education }\end{array}$} & High School & 2 & 0.7 \\
\hline & Diploma/Certificate & 55 & 18.1 \\
\hline & Bachelors & 183 & 60.4 \\
\hline & Masters & 57 & 18.8 \\
\hline & Ph.D./Doctorate & 6 & 2.0 \\
\hline & Total & 303 & 100 \\
\hline Household income & $<$ RM5,000 & 0 & 0.0 \\
\hline \multirow[t]{5}{*}{ per month } & RM5,001 - RM10,000 & 55 & 18.1 \\
\hline & RM10,001 - RM15,000 & 72 & 23.8 \\
\hline & RM15,001 - RM20,000 & 85 & 28.1 \\
\hline & $>\mathrm{RM} 20,001$ & 91 & 30.0 \\
\hline & Total & 303 & 100 \\
\hline Category of & Private Sector & 142 & 46.9 \\
\hline \multirow[t]{4}{*}{ Employment } & Government Linked Companies (GLC) & 10 & 3.3 \\
\hline & $\begin{array}{l}\text { Government Servant (Under Public Service } \\
\text { Pension Scheme) }\end{array}$ & 124 & 40.9 \\
\hline & $\begin{array}{l}\text { Department/ Agencies Under Government } \\
\text { Ministries (Without Public Service Pension } \\
\text { Scheme) }\end{array}$ & 27 & 8.9 \\
\hline & Total & 303 & 100 \\
\hline \multirow{4}{*}{ Sources of Income } & Salary from Employment only & 215 & 71.0 \\
\hline & $\begin{array}{l}\text { Combination of Salary \& Other Non- } \\
\text { Business Income (rental, commission, etc.) }\end{array}$ & 88 & 29.0 \\
\hline & Combination of Salary \& Business Income & 0 & 0.0 \\
\hline & Total & 303 & 100 \\
\hline \multirow{3}{*}{$\begin{array}{l}\text { Any Monthly Tax } \\
\text { Deduction (PCB) in } \\
\text { your salary } \\
\text { payslips? }\end{array}$} & Yes & 303 & 100.0 \\
\hline & No & 0 & 0.0 \\
\hline & Total & 303 & 100 \\
\hline \multirow{6}{*}{$\begin{array}{l}\text { How do you file } \\
\text { your income tax } \\
\text { forms? }\end{array}$} & Personal Computer & 160 & 52.8 \\
\hline & Manual Form & 10 & 3.3 \\
\hline & PDA/ Smartphone/ Handphone & 27 & 8.9 \\
\hline & Laptop & 106 & 35.0 \\
\hline & Never Submit Form & 0 & 0.0 \\
\hline & Total & 303 & 100 \\
\hline
\end{tabular}


Firstly, the scales used in this study were tested for validity and reliability. The table 2 below indicated the scales used were above the threshold limit. All scales recorded values above 0.70 thresholds for composite reliability, with values between 0.929 and 0.954 . In contrast, the AVE recorded values between 0.721 and 0.874 , which are above the 0.50 threshold.

Table 3. Convergent Validity

\begin{tabular}{lcccc}
\hline & $\begin{array}{c}\text { Cronbach's } \\
\text { Alpha }\end{array}$ & rho_A & $\begin{array}{c}\text { Composite } \\
\text { Reliability }\end{array}$ & $\begin{array}{c}\text { Average Variance } \\
\text { Extracted (AVE) }\end{array}$ \\
\hline ATT & 0.909 & 0.921 & 0.936 & 0.787 \\
COMP & 0.933 & 0.934 & 0.947 & 0.749 \\
GTFK & 0.848 & 0.849 & 0.929 & 0.868 \\
INT & 0.928 & 0.928 & 0.954 & 0.874 \\
PEOU & 0.923 & 0.932 & 0.940 & 0.721 \\
PU & 0.907 & 0.910 & 0.931 & 0.730 \\
SN & 0.928 & 0.930 & 0.948 & 0.822 \\
\hline
\end{tabular}

Discriminant validity was also tested on the model of this study. As a multitrait-multimethod matrix, the heterotrait-monotrait (HTMT) was proposed by researchers as an alternative to measuring discriminant validity using Smart-PLS. It was demonstrated by Voorhees, Brady, Calantone that HTMT ratio (Henseler, Ringle, \& Sarstedt, 2015) with 0.85 cut off value, provides incomparable discriminant validity measurement. The table below shows that all figures obtained were below 0.85 . These figures signify the achievement of discriminant validity. However, prior studies had suggested HTMT thresholds of 0.85 and 0.90 for all the constructs (Henseler et al., 2015; Rasoolimanesh, Roldán, Jaafar, \& Ramayah, 2016). All values ranging from 0.266 and 0.778 obtained in this study were shown in Table 3. Hence, as suggested by Henseler et al. (2015), the results of this study fulfil the statistical criteria of HTMT ratio values below 0.90 .

Table 4: Heterotrait-Monotrait Ratio (HTMT)

\begin{tabular}{llllllll}
\hline & ATT & COMP & GTFK & INT & PEOU & PU & SN \\
\hline ATT & & & & & & & \\
COMP & 0.486 & & & & & & \\
GTFK & 0.778 & 0.515 & & & & & \\
INT & 0.709 & 0.419 & 0.725 & & & & \\
PEOU & 0.348 & 0.696 & 0.361 & 0.287 & & \\
PU & 0.722 & 0.662 & 0.773 & 0.606 & 0.547 & & \\
SN & 0.776 & 0.388 & 0.634 & 0.641 & 0.266 & 0.683 & \\
\hline
\end{tabular}

The value of $\mathrm{R}^{2}$ is observed as a measure of model accuracy predictiveness (Hair, Sarstedt, et al., 2014). Alternatively, the effect on endogenous variables by exogenous variables combination is seen as the representation of the $R^{2}$ values that range from 0 to 1 . The $R^{2}$ values of 1 represent complete predictive accuracy. As a rule of thumb to predict accuracy, the $R^{2}$ values of 0.75 are considered as substantial, while 0.50 is moderate, and 0.25 is weak (Hair, Ringle, \& Sarstedt, 2011; Henseler, Ringle, \& Sinkovics, 2009). Hence, the values of predictive accuracy in this research can be seen in the table below.

Table 5. Coefficient of Determination Values $\left(\mathrm{R}^{2}\right)$

\begin{tabular}{lcc}
\hline & R Square & R Square Adjusted \\
\hline ATT & 0.647 & 0.642 \\
INT & 0.435 & 0.434 \\
\hline
\end{tabular}


In PLS-SEM, the path coefficient is used to establish the testing of relationships between variables. Furthermore, the availability of the bootstrapping technique in Smart PLS software was relied upon to test the relationship of this study's hypotheses. As a nonparametric approach, bootstrapping is commonly used to evaluate direct as well as indirect effects (Mackinnon, Lockwood, \& Williams, 2004). In addition, it is commonly known that resampling strategies through the usage of bootstrapping in performing estimation and hypotheses testing. Resampling of bootstrapping techniques performed to obtain path coefficient of hypothesised relationships of constructs that generates t-values for path coefficient significance level assessment of the research model (Hair Jr, Hult, Ringle, \& Sarstedt, 2016). The values of path coefficient values range from -1 to +1 in which near to +1 values represent strong positive relationships. In contrast, strong negative relationships have values closer to -1 (Hair et al., 2014).

As this study obtained 303 samples, the bootstrapping of 500 samples met the conditions suggested by (Hair Jr et al., 2016). All variables, whether independent or dependent, with either direct or indirect relationships, were performed to confirm its relationships. Table 6 and Figure 2 illustrate the direct effect results of the structural model.

Table 6. Path Analysis

\begin{tabular}{lccccl}
\hline $\begin{array}{l}\text { Hypothesised } \\
\text { Effect }\end{array}$ & $\begin{array}{c}\text { Path Coefficient } \\
(\boldsymbol{\beta} \text { value })\end{array}$ & $\begin{array}{c}\text { Standard } \\
\text { Deviation }\end{array}$ & $\begin{array}{c}\text { T } \\
\text { Statistics }\end{array}$ & P Values & \\
\hline ATT $\rightarrow$ INT & 0.660 & 0.042 & 15.777 & $\mathbf{0 . 0 0 0}$ & Supported \\
COMP $\rightarrow$ ATT & 0.059 & 0.058 & 1.017 & $\mathbf{0 . 3 1 0}$ & Not Supported \\
GTFK $\rightarrow$ ATT & 0.326 & 0.073 & 4.448 & $\mathbf{0 . 0 0 0}$ & Supported \\
PEOU $\rightarrow$ ATT & 0.012 & 0.056 & 0.206 & $\mathbf{0 . 8 3 7}$ & Not Supported \\
PU $\rightarrow$ ATT & 0.128 & 0.080 & 1.592 & $\mathbf{0 . 1 1 2}$ & Not Supported \\
SN $\rightarrow$ ATT & 0.430 & 0.068 & 6.318 & $\mathbf{0 . 0 0 0}$ & Supported \\
\hline
\end{tabular}

This study provides a clearer explanation of the relationships as hypothesised. The construct of attitude (ATT) that was decomposed into several dimensions of compatibility (COMP), general tax filing knowledge (GTFK), perceived ease of use (PEOU), perceived usefulness (PU) and subjective norm (SN) provides a clearer explanation of the main construct's measurement. As provided in the table above, the hypotheses of GTFK $\rightarrow$ ATT, SN $\rightarrow$ ATT and ATT $\rightarrow$ INT were all significant. These results represent the significance of general tax filing knowledge, and subjective norm influences their attitude towards their intention to comply with income tax laws voluntarily. However, the hypotheses of COMP $\rightarrow$ ATT, PU $\rightarrow$ ATT and PEOU $\rightarrow$ ATT were not significant as its registered $p$-values $>0.05$. The insignificant of COMP, PU, and PEOU may indicate that the usage of technologies has changed the lifestyles of the respondents, which may not be significant in terms of facilities usage of the system available. Adversely, the respondents may still require the responses from the important people as well as views from others in executing their tax filing duties. In addition, the respondents indicated that general tax filing knowledge is significant towards their attitude in filing income tax forms voluntarily. The significant results show that filing knowledge is indeed very important. At the same time, views from their peers add to their decisions to comply with tax laws. Hence, this study provides a better explanation of factors that may play an important role in taxpayers' voluntary tax compliance intention. 


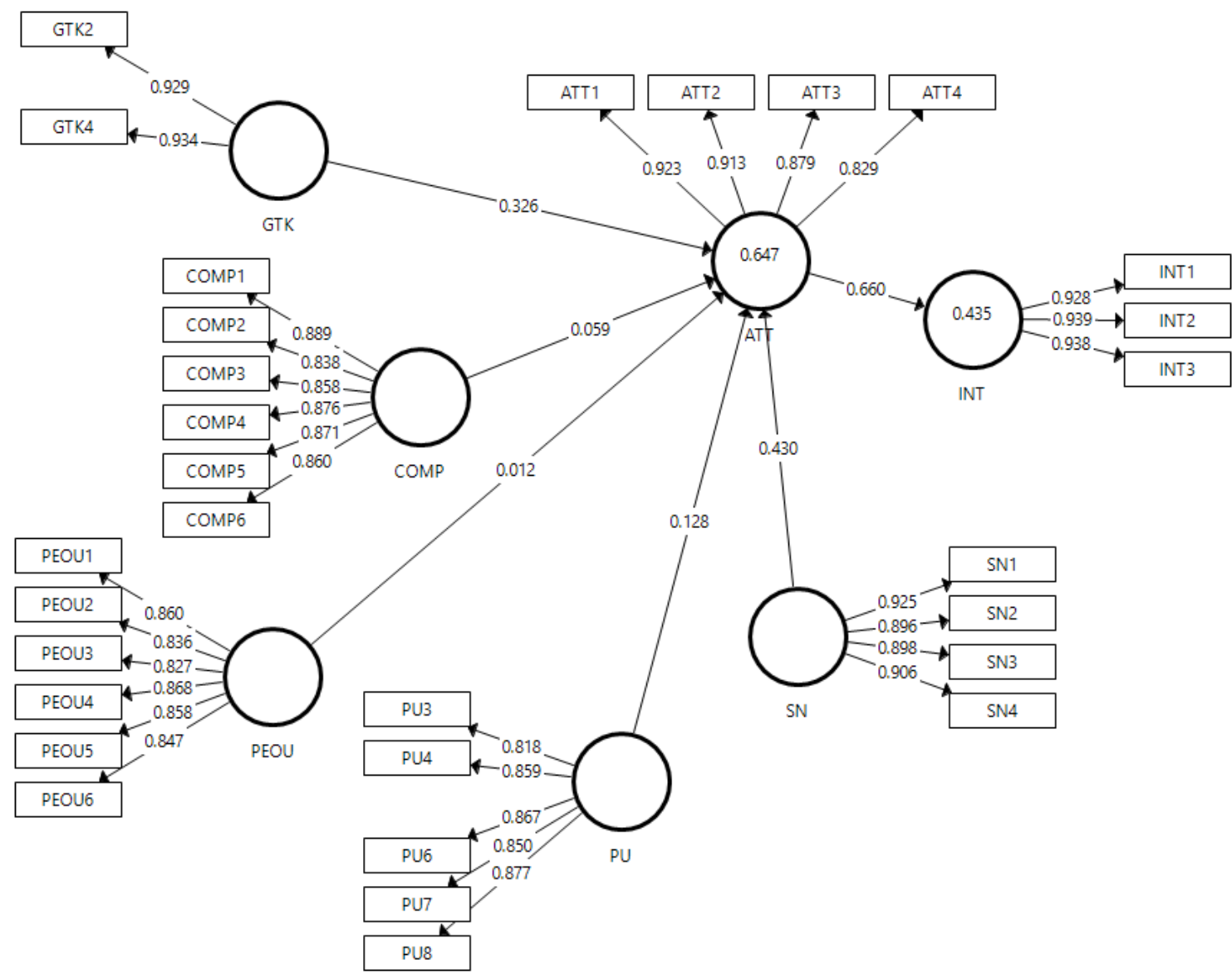

Figure 2. Path coefficients for this study

\section{DISCUSSION AND CONCLUSION}

The intention file income tax form voluntarily depends on the attitude of the taxpayers. In this study, the attitude construct has been decomposed into several dimensions of general tax filing knowledge, perceived ease of use, perceived usefulness, compatibility, and subjective norm. This is to understand the current situation of voluntary tax compliance intention among individual taxpayers in this technologically socialised era. As many taxpayers are utilising technologies, including filing their income tax forms electronically, taxpayers may search for comments and views from sources before complying with tax laws. Their attitude may differ from the views and comments obtained. Hence, the normative belief does influence the taxpayers' voluntary tax compliance attitude. The findings of this study may provide some managerial implications.

The results of this study showed that people surrounding the taxpayer might influence their attitude and decisions to comply with tax laws voluntarily. As indicated in the analysis, COMP $\rightarrow$ ATT, PU $\rightarrow$ ATT, and PEOU $\rightarrow$ ATT was not significant and did not support the study. This showed that most of the respondents are aware of and satisfied with the electronic income tax filing platform provided. However, the respondents may seek better, user-friendlier, and more compatible facilitation towards increasing their satisfaction of the electronic services. Significantly, the respondents acknowledged the significance of 
general tax filing knowledge and subjective norm towards their attitude in filing income tax forms voluntarily.

However, there are several limitations to this study. Firstly, this study only obtained responses from individuals with employment income in which future studies can collect responses from business group individuals or even corporate sectors. Also, the individual taxpayers may be clustered into sectors as comparisons like private and public, age or gender-based, education level as well as location-based studies. Furthermore, the flexibility of decomposed constructs should be extended with several other factors like taxpayers' ability to pay, mass media as referent, and tax officers' attitude towards taxpayers' distress, especially with the current outbreak of Covid19 pandemic. These additional dimensions would provide the outcome of taxpayers' attitude towards voluntary tax compliance during the time of distress faced by many people worldwide.

\section{REFERENCES}

Ajzen, I. (1985). From Intentions to Actions: A Theory of Planned Behavior. In Action Control (pp. 11-39). Springer-Verlag Berlin Heidelberg.

Ajzen, I. (1991). The Theory of Planned Behavior. Organisational Behavior and Human Decision Processes, $50,179-211$.

Ajzen, I., \& Fishbein, M. (1980). Understanding attitudes and predicting social behavior. Englewood Cliffs, NJ: Prentice-Hall.

Apostolou, B., Dorminey, J. W., \& Schaupp, L. C. (2016). Trust in Tax Software as an Antecedent to Intention to E-File. Journal of Forensic \& Investigative Accounting, 8(2), 241-256.

Chen, C.-W. (2010). Impact of quality antecedents on taxpayer satisfaction with online tax-filing systems-An empirical study. Information \& Management, 47(5-6), 308-315. https://doi.org/10.1016/j.im.2010.06.005

Eckhardt, A., Laumer, S., \& Weitzel, T. (2009). Who influences whom? Analysing workplace referents' social influence on IT adoption and non-adoption. Journal of Information Technology, 24(1), 11-24. https://doi.org/10.1057/jit.2008.31

Fishbein, M., \& Ajzen, I. (1975). Belief, Attitude, Intention, and Behavior. An Introduction to Theory and Research. Reading, Massachusetts: Addison-Wesley Publishing Company.

Hair, J. F., Ringle, C. M., \& Sarstedt, M. (2011). PLS-SEM: Indeed, a Silver Bullet. Journal of Marketing Theory and Practice, 19(2), 139-152. https://doi.org/10.2753/MTP1069-6679190202

Hair, J. F., Sarstedt, M., Hopkins, L., \& Kuppelwieser, V. G. (2014). Partial least squares structural equation modeling (PLS-SEM): An emerging tool in business research. European Business Review, 26(2), 106121. https://doi.org/10.1108/EBR-10-2013-0128

Hair, Jr, J. F., Hult, G. T. M., Ringle, C., \& Sarstedt, M. (2016). A Primer on Partial Least Squares Structural Equation Modeling (PLS-SEM) (2nd ed.). London: SAGE Publications, Inc.

Henseler, J., Ringle, C. M., \& Sarstedt, M. (2015). A new criterion for assessing discriminant validity in variance-based structural equation modeling. Journal of the Academy of Marketing Science, 43(1), 115135. https://doi.org/10.1007/s11747-014-0403-8

Henseler, J., Ringle, C. M., \& Sinkovics, R. R. (2009). The use of partial least squares path modeling in international marketing. Advances in International Marketing, 20(2009), 277-319. https://doi.org/10.1108/S1474-7979(2009)0000020014

Inland Revenue Board of Malaysia. (2005). Annual Report, 2004. Kuala Lumpur.

Inland Revenue Board of Malaysia. (2011). Annual Report, 2010. Kuala Lumpur.

Kasipillai, J., \& Mohd Hanefah, M. (2000). Tax Professionals' Views On Self Assessment System. Analysis, $7(1 \& 2), 107-122$.

Lymer, A., Hansford, A., \& Pilkington, K. (2012). Developments in tax e-filing: practical views from the coalface. Journal of Applied Accounting Research, 13(3), 212-225. https://doi.org/10.1108/09675421211281290

Mackinnon, D. P., Lockwood, C. M., \& Williams, J. (2004). Confidence Limits for the Indirect Effect: Distribution of the Product and Resampling Methods. Multivariate Behavioral Research, 39(1), 99-128. https://doi.org/10.1207/s15327906mbr3901

Madden, T. J., Ellen, P. S., \& Ajzen, I. (1992). A Comparison of the Theory of Planned Behavior and the Theory of Reasoned Action. Personality and Social Psychology Bulletin, 18(1), 3-9. https://doi.org/10.1177/0146167292181001

Palil, M. R., \& Mustapha, A. F. (2011). Factors affecting tax compliance behaviour in the self assessment system. African Journal of Business Management, 5(33), 12864-12872. https://doi.org/10.5897/AJBM11.1742 
Rasoolimanesh, S. M., Roldán, J. L., Jaafar, M., \& Ramayah, T. (2016). Factors Influencing Residents' Perceptions toward Tourism Development: Differences across Rural and Urban World Heritage Sites. Journal of Travel Research, 56(6), 760-775. https://doi.org/10.1177/0047287516662354

Schiffman, L., \& Kanuk, L. (2010). Consumer Behaviour (10th ed.). UK: Prentice-Hall.

Sheppard, B. H., Hartwick, J., \& Warshaw, P. R. (1988). The Theory of Reasoned Action: A Meta-Analysis of Past Research with Recommendations for Modifications and Future Research. Journal of Consumer Research, 15(3), 325-343. https://doi.org/10.1086/209170

Trivedi, V. U., Shehata, M., \& Lynn, B. (2003). Impact of Personal and Situational Factors on Taxpayer Compliance: An Experimental Analysis. Journal of Business Ethics, 47(3), 175-197. https://doi.org/10.1023/A:1026294332606

Voorhees, C. M., Brady, M. K., Calantone, R., \& Ramirez, E. (2016). Discriminant validity testing in marketing: an analysis, causes for concern, and proposed remedies. Journal of the Academy of Marketing Science, 44(1), 119-134. https://doi.org/10.1007/s11747-015-0455-4 